\title{
Islamic College and Local Culture: Internalization and Integration
}

\author{
Fulan Puspita \\ Pascasarjana UIN Sunan Kalijaga, Yogyakarta, Indonesia \\ fulan.puspita@gmail.com \\ Zulkipli Lessy \\ Pascasarjana UIN Sunan Kalijaga, Yogyakarta, Indonesia \\ zulkipli.lessy@gmail.com
}

\begin{abstract}
This study aims to determine Indonesian Islamic values' integration and internalization in building students' personalities as teacher candidates. The research method used is a qualitative phenomenological approach. The data source comes from the head of FTIK Salatiga State Institute for Islamic Studies (IAIN), five lecturers, and 25 students. The study concludes: (1) stage of value transaction is conducted in every college activity either inside the class or in the campus environment by considering laws, social regulations, and obligations attached to every student in preparing them to return serving the community and state as well as religion. (2) Stage of the social contract. In this stage, the student has acted by considering that they have certain obligations toward society and certain obligations to them. (3) Trans-internalization stage; students have found values, and they regard them as universal values that influence an individual's character. In all the steps, the more measures developed will be instilled within the student to take a strong effort and relatively-long enough time to reach the desired outcome.
\end{abstract}

Keywords: Internalization; integration; Indonesian Islamic values; student's character 


\begin{abstract}
Abstrak
Penelitian ini bertujuan untuk mengkaji peran yang menentukan bagi terwujudnya intergrasi dan internalisasi nilai-nilai Islam Indonesia dalam membangun kepribadian mahasiswa sebagai calon guru. Metode penelitian yang digunakan adalah fenomenologi untuk menggali data, yang bersumber dari Dekan FTIK IAIN Salatiga, lima dosen, dan 25 mahasiswa. Hasil penelitian menyimpulkan: (1) tahap transaksi nilai dilakukan di setiap aktivitas diluar maupun didalam kampus dengan mempertimbangkan aturan-aturan, regulasiregulasi sosial, dan kewajiban-kewajiban pada setiap mahasiswa dalam mempersiapkan diri untuk mengabdi kepada masyarakat, negara, dan agama. (2) Tahap kontrak sosial ditandai ketika para mahasiswa mempertimbangkan bahwa mereka memiliki kewajiban-kewajiban terhadap diri dan masyarakat. (3) Tahap antarinternalisasi terjadi manakala mahasiswa telah menemukan nilainilai, dan mereka anggap sebagai nilai-nilai universal yang mempengaruhi karakter diri. Pada seluruh tahap, jika penanaman nilai banyak dilakukan maka akan tertanam dalam diri, dan hasil yang diinginkan akan diperoleh meskipun memakan waktu.
\end{abstract}

Kata kunci: Internalisasi; integrasi; nilai-nilai Islam Indonesian; karakter mahasiswa

\title{
A. Introduction
}

Internalization is defined as a combining or unifying attitude, or standard of behavior, or opinion, etc., within the personality. Integration is a specific knowledge theory that needs to be confirmed with religious knowledge or vice versa, so that each may correct the other. People regard values as having essential meaning in their life by functioning as a reference for acting and behaving. According to Lickona, character-building consists of moral values used as guidance in behavior, so humans will behave as they are supposed to do. Values form character and personality which are being used as a foundation in thought, attitude, and action (Berkowitz et al. 2020, 114; Lickona, Schaps, and Lewis 2007, 50).

Islamic educational colleges, generally and currently, continue to follow the classical knowledge platforms dominated by 'ulûm al-shar'î, which its epistemology is based on the classical historical evidences while ignoring current advances. Therefore, such tradition has set a gap in today's knowledge of science and technology, both of which have rapidly developed in the modern period to deeply influence human civilization. The lag of Islamic tradition may affect Islamic educational colleges to deal with three problematic situations: (1) an endless 
dichotomy between religious knowledge and general science; (2) alienation of spiritual knowledge from the realities of modernity; (3) dismissal of scientific advances from having a connection to religious values.

Because of this rift seen in Islamic educational culture such as the backward in science and technology as well as the negativity of technology informatics influencing adolescents and young people, these situations suggest Islamic colleges to integrate Islamic values with the existing local culture to develop and make progress amid modernization and digitalization. Internalization can allow Islamic colleges, which emphasize Islamic values, to become one unit harmoniously enriched by scientific knowledge. This objective is to incorporate Islamic knowledge with science so that there is not a dichotomy. Virtually, discourse on integrating science with Islamic religion within Indonesia's Islamic universities has arisen since the beginning of 2000s with the establishment of Islamic universities (Abdullah 2017, 392). Such integration needs ongoing support and modification to correspond with existing science and to restore Islamic teaching into science as being not just a myth.

Internalization is conducted by combining values into a person or adapting the beliefs, values, attitudes, practices, and standard rules (Mulyana 2004, 21). The processes for values understanding must be practiced in order for values to affect attitude and to have permanent outcomes within a person (Ihsan 2011, 155; Rumiani 2006, 45). Thomas Lickona emphasizes that there are ten signs, within an era, that point to the need for awareness of precarious symptoms already existing. These ten signs, indicating that a nation is heading to the brink of extinction, are: increased violence, frequent use of harsh words and languages, peer-group influence toward violence, increased negative behaviors, fading of moral guidelines, decreased work ethos, lowered respect, lowered responsibility, dishonesty permeating a culture, and sowing hatred among humans (Lickona 2012, 39).

Without much notice, teenage behavior development in Indonesia had headed toward the signs mentioned above by Lickona. The increasing incidence among teenagers of violence, drug abuse, and antisocial behavior is a social problem that has not yet been fully addressed. Violence issues start with bullying. Acts of bullying occur because respect for fellow-friends, parents, and teachers has been lost. As much as 84 percent of children in Indonesia have experienced violence at school. This incidence level of violence cases is higher than in Vietnam (79\%), Nepal (7\%), Cambodia (73\%), and Pakistan (43\%). Moreover, data from the United Nations organization for children (UNICEF) states that one out of three girls and one out of four boys in Indonesia have experienced violence. A student in Surabaya ended a friendship because of jealousy, a high school student brawl in Jakarta took lives and caused casualties, and 
many more such incidents have occurred. These harms are evidence that many problems are occurring in this country's education. There is a great need for mental revolution in education (Setiawan 2018, 1; Zubaedi 2011, 34).

We must admit that not all internet usage or social media bring negative impacts. However, today's problem is that users of the internet and social media are a mix of ages and affinity groups, many of whom do not filter their social media sources nor learn how to use the internet wisely. Different factors causing character deterioration in neighborhood show a failure of education as applied within the family, the school, and the community. There is a deficit in directing teenagers and children toward having a strong character and noble ideals. A handful of recent studies have revealed adolescents involving in unlawful attitudes yet crimes. Syafi' AS and Rahmawati (2019) asserted that adolescents in Jombang of East Java have committed delinquent attitudes during school hours, and these attitudes are concerning educational stakeholders. Such delinquencies are violence, absence from school hours, ignorant of doing assignments, smoking, and other unacceptable behavior. These authors have recommended that Islamic religious education teachers should take concrete actions in overcoming these problems. Although referring to high school settings, the case may significantly affect the teachings in higher Islamic educational institutions (Syafi'AS and Rahmawati 2019, 1). In line with the above case, Susanti, Suryadin, and Sumantri (2020), who conducted a longitudinal study on adolescence from 2017 through 2019 in the region of West Bangka of Bangka Belitung, reported 18 juvenile delinquency cases ranging from light to heavy crimes which were committed by the adolescents. Of the main findings revealed and of which are relevant with this existing research are stealing, pornography, drinking, violence, and drug abuse (see also Suryani, Hardika, and Rini 2020, 129). Susanti et al. (2020) research has recommended that educational institutions should forge youth character in order to prepare young people with better future. Islamic education teachings at the higher institutional levels have been focusing the efforts on molding good, solid characters of their students, and as such, an example drawn is from the mission of the Tarbiyah and Teaching Faculty of IAIN Salatiga, which is to educate young people to become scholars with high, noble character and, ultimately, they will be beneficial for self, religion, and the nation.

A similar focused topic of discussion on adolescence and delinquency can be seen in a study entitled 'A Phenomenological study: Youth experiences in abusing drugs', revealing that negative effects of illicit drugs will last longer in their future life, yet the short-term effects include unhealthiness, feeling of lack of trust from the family, and school dropout (Suryani et al. 2020, 130). Other research studies have also revealed general juvenile delinquency among 
high school students in Serang, Banten and Salatiga, Central Java respectively. The first study was conducted by Wahyudi and Nurmala (2020), and in their findings the juveniles were offensive to public rules and had unacceptable attitudes such as school truancy, bullying, smoking, and premarital sex. The second study of Karlina (2020) found that emotion upheaval, withdrawing from family, and being social offenders are common phenomena among teenagers. Thus, educators and communities have great responsibilities in tackling the delinquency. In this context, the researchers believe that the IAIN Salatiga needs to forge its role in shaping students' behavior with Islamic teachings, such as the Qur'an and hadith because the students come from different backgrounds socially, economically, politically, spiritually, culturally, or religiously.

Character-building is urgently needed via higher education in order to strengthen the nation's youth with a mentality for "good character, high patriotism, and nationalism to achieve wise governance" (Sutjipto 2011, 501). There are some Islamic colleges that have applied character-building as reported in the study conducted by Puspo Nugroho, a lecturer in Kudus State Islamic College (STAIN), who shows that character-building in higher education is carried out through practicing the threefold missions of higher education (Tri Dharma Perguruan Tinggi). The strategy emphasizes "lecturing structure, socialization, creating harmonious relations, being humane and religious, being friendly, prioritizing compassion, becoming accustomed to engage in positive activities, building each student's positive mindset, providing meaningful learning, using lectures as the living model, and integrating Islamic teaching values" (Nugroho 2017, 355).

The same conclusion is also discussed by Wathoni, namely that character-building internalization at a Tarbiyah department is achieved via various models, namely (1) "conducted in the learning process during lecture; (2) shown in academic administration service, and (3) carried out by student's participation in extracurricular activities" in Tarbiyah Department STAIN Ponorogo (Wathoni 2016, 10). Furthermore, Lukis Alam, who conducted a study on Islamic educational values in STTNAS Yogyakarta, reveals that students very much need to be instilled with Islamic values during college in order to build human resources based on Qur'an and the Prophet Muhammad's Sunna. Religious activities on the campus become important agendas for Islamic religious education affiliation held in the classes, also known as campus da'wah (LDK). Via LDK, there is an expected strengthening and internalizing of students' Islamic values (Alam 2016, 101).

Some of these studies show that character-building in higher education, either religious or public, is vital to achieve the national educational objective and generate graduates 
with good character and teacher's candidates with strong-positive character. Teachers are the front liners for attitude building, behavior, and transferring the learning goals toward the student either individually or group. It would be unimaginable what the country's future generation would be, while without the contribution of a professional and robust personality teacher. One of the alternatives in instilling great Indonesian values is by education. Therefore, before becoming a teacher, the teacher's candidate must be supported by positive principles and good character through character-building and internalizing values.

Character-building is also conducted in Indonesian Islamic colleges, notably in Tarbiyah and Teaching Faculty, to internalize and integrate Indonesian Islamic values for instilling graduates with religiosity and noble culture. Unifying Indonesian Islamic values within teacher's candidate graduates in FTIK State Institute for Islamic Studies (IAIN) Salatiga is crucial to produce internalization and integration of Indonesian Islamic values. The values are being taught and instilled within students' personalities and daily attitudes so that they can be the role models for their students.

Accordingly IAIN Salatiga has integrated the triadic model in the teaching process. It is perceived as a unity model based on the number of basic concepts becoming the core elements of the model (Bagir 2005a, 27; 2005b, 4). The model has threefold: (1) monodic model which perceives that religion is the only truth while science is a branch of culture. (2) Dyadic model supports the integration of science and religion. (3) Dialogue model is seen as two diagrams that reciprocally overlap, and this highlights the meeting point of science and religion. Thus, the triadic model is a response toward the independent dyadic model. In this model, a catalyst exists so-called philosophy aimed at bridging science and religion. Therefore, internalization is applied through three dimensions (Muhaimin 2014, 56). At IAIN Salatiga, the concepts of integration and internalization are designed to meet the objective of graduates who can teach professionally at primary and secondary education. The graduates are prepared with spirituality and local based cultural competences.

Given the literature reviewed, the researchers have found three general conclusions: first, the shift of roles and responsibilities of the State Institutes for Islamic Studies and State Islamic Universities in Indonesia to become wider because they hold critical tasks. Some of them is a change of paradigm in Islam as was previously seen merely as 'ibadah (worship) to a catalyst of social, cultural changes because of the rapid social shifts. These changes are unavoidable, and youths currently learn beliefs and religious teachings from many sources such as the Internet. It is considerably important that Islamic higher educational institutions, such as IAIN Salatiga, should play a community chest role to ameliorate the social impacts from 
outside that do not reflect noble, high values of Islam. Second, the character building among youths in Indonesia is viewed important because the youths are the sustaining generation and will be leaders in the future. The collapse of the nation is determined by the youths' character, as if they can build ethos and good nation characters stemming from their own history then their nation will sustain. Our nation' values such as Pancasila and Islam are two examples of which IAIN Salatiga should conserve them so that students of different backgrounds will hold these ideologies. Third, a number of research studies above has shown that the negative effects of juvenile delinquency are disrupting our ideologies. Nowadays, drugs, pornography, violence, burglary, premarital sex, and other negative unacceptable attitudes are ubiquitous and done by our irresponsible youths and, therefore, this current study examines how IAIN Salatiga integrates Islamic Indonesian values into curricula for teacher candidates in order to instill strong positive character traits. Our qualitative field research gathered direct observations and used a phenomenological approach (Pashiardis et al. 2011, 99). Analytical descriptives were employed to carry out thematic analysis.

\section{Method}

In order to accomplish this study, the researchers purposively elicited a group consisting of the head of faculty, five lecturers, 25 students, and related subjects. The head of the faculty was chosen due to being the initial policymaker. Lecturers in Indonesian Islamic history were chosen due to having the direct responsibility for implementing such curricula. The 25 students chosen were those being taught by the five lecturers and evincing a level of success in reference to internalization and integration of the Islamic college and local culture. These students performed Zuhur prayer and Friday prayer in congregation, were accustomed to recite and memorize Qur'an verses before each lecture, and had participated in local cultural courtesies and extracurricular cultural activities, such as wearing Karawitan attire as appropriate to Islamic sharia and local courtesies.

Data were collection employed a multi-method approach, consisting of interviews having semi-structured patterns, information from Islamic college documents, and observation as well as records revealing Islamic college internalization and integration aligning with the existing local culture in Java Island, particularly in Salatiga. Examination of the earlier interview data validity was conducted through data source triangulation and varied data collecting methods, observing integration and internalization of Islamic college values with local Javanese culture, and reviewing related documents. Interviews with the head of FTIK IAIN Salatiga and the lecturers were done in face-to-face sessions on campus. Observation of character 
development covered students' activities during time in IAIN Salatiga. Document review covered all relevant documents collected in this research.

Adapting from Miles and Huberman (1994), data analysis started from the data collection stage, namely observation, interview, and field notes conducted by the researcher. The data were reduced, selected, categorized, and classified as to the internalization and integration of Islamic colleges and local culture. The data display conveys a representation of the pattern of internalization and integration of Indonesian Islamic values presented. Processes for data validity production, triangulation and iteration were conducted while maintaining "credibility, transferability, dependency, and confirmation" in collecting data (Creamer, 2018, 51). Lastly, cross-checking and diversifications done through triangulation theory (corrective internalization and integration stages theory of Indonesian Islamic values) achieve conclusions in data analysis (Huberman and Miles 2002, 24; Miles and Huberman 1994; Miles, Huberman, and Saldaña 2018; Sugiyono 2010).

\section{B. Discussion}

\section{Indonesian Islamic Value Internalization and Integration}

The concept of 'internalization' is defined as the integrated attitudes and standard behaviors and opinions of a person. According to Reber in Mulyana (2004), it refers to someone who internalizes his or her values in order to adapt with their beliefs, values, and attitudes. These ultimately become practical and customized norms in oneself (Mulyana 2004, 40). This definition indicates that understanding of values infers practices and, thus, implies attitudes. The internalization is permanent in oneself. Ihsan (2011) has defined 'internalization' as an individual practices his or her values and, therefore, claims the values as his or her own (Ihsan 2011, 154). Thus, internalization can occur in all dimensions of education and at all levels of education. While integration is an immersion of self into other values to become integrated parts. Kamus Besar Bahasa Indonesi (Poerwadarminta 2014, 362) defines the word 'integration' as "involving a variety of groups into an integrated territory and, thus, molding new identities". Bahar (1991) asserted that integration is a process of immersion in finding ways of uniting separate elements to become a new identity (Bahar 1991, 2).

The Tarbiyah and Teaching Faculty (FTIK) IAIN Salatiga performs its role and function to provide guidance in implementing higher education's threefold missions. The FTIK visions are to excel in developing Islamic Indonesian values-based education. The Department of Islamic Religious Education's vision is to become a center of excellence in 
teaching, research, and developing research-based Islamic education in 2025. Within these missions are (1) organizing centers of excellence in education designed to create professional graduates by developing values, ethics, and moral preparation for students to become Islamic religious teachers; (2) preparing qualified graduates who have spiritual piety, noble character, a wide range of knowledge, and professional maturity in performing their duties as Islamic religious teachers; and, (3) developing a new paradigm for creating a religious and academic climate in managing education and developing competency for Islamic spiritual teachers.

The integration applied at IAIN Salatiga is the triadic model using science, spiritual values, and local cultures. This combination was developed as an expansion of the curricula at IAIN Salatiga. Back to his history, the former rector of IAIN Salatiga, Rahmat Hidayat, has contributed to this integration during which time the IAIN had just changed its roles from a small college (STAIN) to become a biger influencing institution (IAIN). With this transformation, students at FITK would be studying a variety of disciplines, and this has increased their theoretical foundations and critical thinking. The institution with new mandates then has equipped the students with spiritual values and cultural sensitivity before being deployed as teachers at school. Thus, the integrated dimensions could generate the Indonesian cultures of Islamic religious teachers. Clearly, this has been developed through the curricula. Part of the curriculum development to integrate Islam and local cultures was the establishing of some Indonesian-based subject courses such as Indonesian Islamic History. Several local cultural activities, such as the Gamelan show, were part of this strategy.

Typically, Indonesian Islamic history does not focus on Javanese Islamic culture, even though it including material on how Islam spreads in Indonesia with various local cultures, as carried out by Walisongo. One example is conducting da'wah using the Leather Puppet show (Wayang Kulit) medium. This enjoyable Leather Puppet was integrated with Islamic values, so that, gradually, people who were watching it could understand more about Islam. And it is presented in a light-hearted way without coercion. It aligns with the basic principle for IAIN Salatiga to build local culture-based scientific integration.

IAIN Salatiga, as illustrated by their institutional logo, focuses on strengthening Islamic and Indonesian values simultaneously. The logo conveys a multi-part philosophical meaning. The Globe illustrates the islands and Indonesian territory to reflect that IAIN Salatiga is based on Indonesian values and diversity. The Opened Book/Scripture represents scientific grounds and a fondness for knowledge and passion in jihad. The two wooden stands represent the two bases of the vision of IAIN Salatiga, namely the Islamic and the Indonesian values. The curling leaves symbolize loving the environment, socializing, and living with 
nature. Six of the leaves symbolize pillars of faith. The other six leaves show the world creation process, viz. within six days, and the five books/five stacks of books represent Islamic pillars. The 17 lines within the book represent daily prayer, consisting of 17 rakaats, and also the date of Indonesian Independence Day. The green color represents peace, growth, prosperity, and environmental benefits. The yellow color in the book and the leaves' tips represent the soul's dignity and greatness. The blue color in the globe represents confidence, independence, technology, and broadness. The brown color of the book stacks represents being strong and sturdy as an Indonesian culture entity, and the word IAIN Salatiga is its name and location.

IAIN Salatiga's Rector stresses his commitment to expand the role and contribution of the institution in general. The FTIK particularly aims to strengthen tolerance values and diversity, as well as to provide awareness and understanding to its students and stakeholders. The emphasis is on existence not just as Muslims located in Indonesia, but more particularly and also generally, as Indonesian people who are religious (Cahyono 2016, 67; Tricahyono, et. al, 2020, 1). As for the stages in Indonesian Islamic values, the internalization in FTIK IAIN Salatiga exists as follows:

\section{Values Transactions Stage}

FTIK IAIN Salatiga conducts the value transaction stage in every lecturing activity, both inside the classroom and in the campus environment. This includes considering laws, social regulation, and obligations for every student, as they prepare to serve the wider society, the State, and their religion. These transactions are conducted by active classroom discussion between lecturer and students, so that the students are prepared to practice the values in the wider community.

Endah Kurniawati, as the lecturer in Indonesian Islamic History, conveys that in teaching SII, in the $4^{\text {th }}$ and $5^{\text {th }}$ meetings, the students must make observations directly in the field in order to see the development and communality of Islam and Javanese culture. This brings an understanding that Islam and Javanese culture are not contradictory items. The outlook is also revealed by Bekti Taufiq Ari Nugroho, who conducts observation of some Islamic boarding schools in Salatiga. Students observe and do simple interviews with the students or teachers in the Islamic boarding school to find out the history of establishing the school. The result derived is that mostly Islamic boarding schools were built with self-sufficient community funding around the Salatiga area and that typically the schools still preserve local culture, such as Tahlilan. 
According to Wildan and Arif Bagas, experience in observation and field surveys, looking at acculturation outcomes of Islam and Javanese culture, makes students understand aspects of the local culture that they may have previously overlooked. Students can learn that even the most basic cultural symbols are based on established philosophical bases and historical values. One such lesson learned via observation is that the Sea Alms activity, which conducted at the seashore every Suro month, embodies Javanese culture. It also is enriched with $d u$ 'a (prayer) and preaching, which reminds every citizen along the seashore to always live in harmony with nature, not to handle sea products roughly, and to donate some of their sustenance to other people either directly or when gathered together to conduct a feast.

IAIN Salatiga also provides students with facilities to develop talent and skills in art performances through extracurricular activity. IAIN Salatiga has Karawitan Pemandu Sabdo. This group elaborates a connection between Javanese Gamelan arts and Salawat. The group has actively participated in events both on and off campus, as in Salatiga, Semarang, and other Central Java regions. Another group, the Karawitan Pemandu Sabdo, was formed to conduct exercise every Sunday. The objective is to develop talents and skills and to foster mental and spiritual growth in IAIN Salatiga.

While in the campus environment, students and the FTIK academic community also have the custom of conducting congregational daily prayer. The prayers performed in congregation are Zuhr and Friday Prayer. The objectives are for the members of the academic community to know each other, to value togetherness, and to create a dignified and peaceful culture on campus. One such method is having the sixth term end at $11.45 \mathrm{am}$, so that all lecturers and students can then perform congregational Zuhr prayer at noon and Friday congregational prayer at PTIK IAIN Salatiga.

\section{Social Contract Stage}

In this stage, students learn to consider their obligations toward the community and, conversely, to know that the community has certain obligations to the students. This social contract is emphasized by awakening awareness by the students as they participate in classes during college hours and as they perform organizational activities within IAIN Salatiga. As teacher candidates, they are being prepared for their service as front-liners for maintaining and strengthening society.

Students, when returning to the community after studying transactional values in their Indonesian Islamic History course, have gained exemplary da'wah values of the Walisongo to apply in their daily lives. Students in wider community environment then exhibit the values 
obtained by appreciating differences. Courses taught with Indonesian and Islamic values encourage practices for acting politely, religiously, and pleasantly in the broader environment. The purpose is for graduates of IAIN Salatiga to become teachers who pleasantly deliver knowledge while teaching academically and valuing the local culture.

The students' attitude toward their environment influences their social effect both on and off campus. For instance: in FTIK IAIN Salatiga there is a White Friday policy, whereby all the lecturers, staff, and students are obliged to wear white Taqwa shirts, dark-colored pants or skirts, and shoes, per the rules in IAIN Salatiga. Further details of the dress code are as follows: students are not allowed to wear t-shirts, torn clothing, sarongs, slippers, hats, long hair, dyed, earrings, necklaces, or bracelets, nor to have a tattoo, when participating in academic activity, administration service, and campus activities. It is forbidden for girls to wear tight dresses or skirts, or translucent clothing, or to go without veiling when participating in campus activities. Those who violate these rules are given a reprimand and written sanction and will not be allowed to serve in administrative or academic activity, nor to participate in lectures.

Mr. Ahmad Sulton tries to engage FTIK IAIN Salatiga students to naturally build social contracts and to focus on awareness of their responsibility as the earthly caliphate. He exhorts students to return to the community and serve as recitation teachers. Also, students must participate in mutual assistance on campus and in the surrounding neighborhood of their boarding house. These activities are hoped to allow students to learn how to be good members of society, to become familiar with the existing local culture, and to be able to build connections in the social environment.

The same opinion was also expressed by Anindita Kartika and Imroatul Rofiah. The experience of serving in the community during the two-course meeting is augmented by teaching recitation, participation in mutual assistance in the neighborhood dormitory, assistance in an orphanage and Islamic boarding school in Salatiga town, and learning to socialize and bond with the surrounding communities. This helps students understand the essence of returning usefully to society after graduation and becoming teachers therein.

The dress code for students is implemented at the beginning of all new students' arrival. Thus when they start to be active in IAIN Salatiga, they already understand the dress code is and the school rules. Students thereby are learning to dress up as the habit of a teacher when going to school. When the students return to society and start teaching, their attire will suit the role of a teacher and will uphold religiosity, courtesy, and typical Indonesian values. 


\section{Trans-Internalization Stage}

This is the highest stage, where the students find the values regarded as universal. The values become principles influencing their attitudes and instilled into their personality. This is seen in their daily behavior, be it their housing, on campus, or in society's environment. Everything taught, discussed, and applied in the students' campus environment after studying in FTIK IAIN Salatiga has been deeply embedded, so that each student has formed a religious personality with love for the homeland and without radicalism in beliefs or actions.

As in the activities carried out before the lecture begins, they recite and memorize short verses previously provided by FTIK IAIN Salatiga. It is conducted for the first 15 minutes of the first term lecture every day. This habit also supports the presence of Qur'an course subjects for fresh students in the first semester. This course contains how to read Qur'an correctly and in the right manner. Students are also taught tajweed and obliged to memorize Juz Amma entirely. The goal of this objective is that all students can recite and memorize Qur'an, at least Juz Amma. When they return to society, they may become recitation teacher in the Mosques or TPA/TPQ (Afternoon Qur'an Schools for Children). Many students who previously do not fluent in reciting and then become fluent and have the courage become recitation teacher in TPA/TPQ in the neighborhood surrounding IAIN Salatiga or their resident.

\section{Integrating and Internalizing Indonesian Islamic Values}

Research findings in observation, interview, and documentation interpreted that integration and internalization conducted in this study put a focus on values. The values developed in Indonesian education come from four sources, namely religion, the state ideology of Pancasila, culture, and the Acts on National Education System 2003. Indonesia acknowledges several beliefs officially, and every institution is obliged to teach about religion to their students according to their faith, but not in the form of religious indoctrination. The educational institution also must teach Pancasila values and Indonesian culture to achieve the National education objectives. It is considered essential that Indonesian Islamic values be internalized by students in all Islamic educational institutions in Indonesia, with the goals of reducing radicalism and keeping peace in the country. Hence, Indonesian Islamic values internalization is essential for Islam to function as a religion that acknowledges and upholds Indonesia as a peaceful and prosperous country into the students' minds. Those values are reflected in and by the attitudes and behaviors shown in daily life activities. 
FTIK IAIN Salatiga's vision indicates that the integration pattern should be applied to align science and Islam, connecting them with each other and using Indonesian values (local Javanese culture). The PAI Department's mission exhibits the seriousness of IAIN Salatiga in producing professional graduates who have Islamic and Indonesian values, which are unique. The profile desired for a PAI teacher candidate, as educated by IAIN Salatiga, includes ethics, academics, professional maturity, spirituality, and morality, all instilled to the fullest extent possible in the religious educational climate. This emphasizes not only academic values, but also religion and a connectedness with local cultural values.

The IAIN logo itself displays the focus on strengthening Islamic and Indonesian values simultaneously, based on the vision in IAIN Salatiga. And in its philosophical meaning, the interpretation is that IAIN Salatiga is established based on the integration of science, Islam, Indonesian culture, and diversity with passion in jihad. Implementing knowledge includes loving the environment, socializing, and building a peaceful and prosperous life. The graduates' character is expected to evince high confidence, technological savvy, and keeping up with current developments, while also being unwavering in preserving Indonesian cultural identity, especially as locally imbued.

Internalization is carried out via three doors. First, the institutional door accesses the existing institutions, such as an Islamic Studies institution. Second, the personal door is primarily accessed with the aid of the lecturer. And third, the materials door accesses curricular design and lecture content. Then there are the three stages in the internalization process: values transformation (information about a value), values transaction (interaction feedback), and trans-internalization (Muhaimin 2014). The integration model implemented at the IAIN Salatiga is by means of combining those models mentioned through: first, institutionalizing the mission which reads, "conducting education, research, and community service in a variety of Islamic disciplines and Indonesian courses related culture. It also builds the academic society with Islam and Indonesian values." It is clear from the mission state that IAIN Salatiga has sought to integrate values of Islam and Indonesia in order to enhance the institutional capacities. Second, building students' character starts from establishing the teachers' role as models. To attain this aim, it held several training of trainer (TOT) programs and courses related character building for the teachers in 2018. Meanwhile the objective of the TOT was to yield teachers who can guide religiosity of students so they have good attitude and academic competencies. Third, curriculum development was initiated to yield outputs who have Islamic Indonesian values by providing courses such as history of Islam and Indonesia. The subjects of this study are the students. They have experienced values transformation earlier in their 
educational institutions before entering college. Higher education then continues the internalization by developing a more thorough knowledge of values, as for the process of Indonesian Islamic values transaction. The lecturer can be an excellent example for the students, in order to present and instill a religious personality so that appreciation of the culture and of Indonesia as a sovereign nation. The stages of Indonesian Islamic values internalization in FTIK IAIN Salatiga are as follows:

\section{Stage of Values Transaction with Law and Order Orientation}

Before entering this stage, students should already have experienced earlier stages of values transformation. However, for students 18 to 25 years old, the transformation stage is combined with the transaction stage. By contrast, it was conducted in two ways with direct discussion of concrete examples since they have already understood the core values as obtained from previous education institutions. Hence, when students enter college, what needs to be done is to elaborate and practice these values.

In examining values transaction implementation, carried out in FTIK IAIN Salatiga, it was found that this stage is conducted by introducing a set of rules in the campus, related to either academic or social practices, and explaining every student's obligations, as necessary both during their term of study and then after graduation. Introduction patterns are given formally during the lectures directly in class or during new students' orientation period. When they actively study, they already know the campus regulations and their obligations as students in FTIK Salatiga.

During studying on campus, students are taught with the field of study approach pattern. This field study is conducted based on the SII course requirement to see the actual proof of acculturation between Islam and local culture. The activity is still supervised by lecturer and permitted by FTIK. The field study is conducted by observing historical buildings, such as a tombs, mosques, and Islamic boarding schools around the campus. This is proven to help accustom students to their surroundings.

Introduction to local culture is conducted in IAIN Salatiga by creating a Karawitan Pemandu Sabdo Group. This group succeeds in combining the art of gamelan with modern Salawat. The gamelan art corresponds to the current music preferences of the youth. The Salawat is updated to include recent popular songs. Thus trendy songs will be combined with Salawat to attract IAIN Salatiga students to engage the art of Karawitan. Student creativity in developing music and song in Karawitan is not limited, so long as they do not break Islamic Sharia or cultural rules. 
In the implementation of congregational prayer in IAIN Salatiga, the researchers observed values of togetherness shared between the academic community and the IAIN Salatiga environment. There is no distinction between lecturer, staff, or students for Shalat (prayer); rather it occurs for all in the same place. Before and after prayer is finished, the researcher saw that it spurs transaction values among academic members by means of discussing non-formally any recent updates. This methodology is the informal rule (unwritten) in IAIN Salatiga.

The lecturers are role models for the students to exemplify the values of the academic community. Human nature tends toward imitation and thus the environment affects behavior. Emulation of a good example leads to useful behavior, and vice versa. The lecturers also have an essential role to act according to Islamic values and tradition, such as exhibiting polite behavior in the campus environment, teaching with courteous language, being straightforward, and not threatening anyone. Gradually, these values are spread from lecturers to students during their interactions on campus.

\section{Stage of Social Contract Legalistic Orientation}

Most students in their social neighborhood start to apply unwritten social contracts amid the surround environment. In this stage, the students have an awareness of their position within society and begin to build a unique student personal image within their environment, as on campus, in boarding houses, or residing in the local community.

Such social contract formation makes students realize that every action conducted in a social environment will have social impacts. For instance, values transactions are carried out in IAIN Salatiga by imposing dress code to students and the entire academic communities, and specifically to wear white Taqwa clothes, dark-colored pants or skirts every Friday, which is called white Friday. Therefore, every Friday the entire academic community wears clothes according to the rule. When a lecturer or student does not follow the regulation, they will experience social sanctions and feel abashed because his clothes are different from everybody else on campus on that day. Hence, awareness to follow a rule is shaped by the community itself.

The social contract also builds inside the class by applying community-based learning. Students are given two free-time meetings to serve the community, in ways such as teaching recitation or participating in mutual-assistance on campus or in the surrounding neighborhood boarding houses or residences, and participating in social activities as with Tahlilan Akbar and 
so forth. Such actions encourage students to care about their environment, neighbors, and culture, rather than ignoring their surroundings.

\section{Stage of Trans-internalization with the Universal Ethical Principle Orientation}

This is the concluding stage of internalization. When the students have entered the trans-internalization stage, they have found the universal values developed in their social environment and have set these as their own values. The character of a PAI teacher candidate is formed thereby to professionally, spiritually, and academically accord at a high level with FTIK IAIN Salatiga vision and mission.

Students who graduate from FTIK IAIN Salatiga can teach Islam from many perspectives and do not impose rigid doctrine. Notably, it is seen that there no graduates from FTIK IAIN Salatiga who ever become affiliated with, or active in, 'radical' social organizations, nor in radicalism. Through the values obtained and practiced during college at FTIK IAIN Salatiga, students are expected to be pioneers in Islam as rahmatan lil'alamiin. They stand against radicalism; they fully support the Republic of Indonesia; and they do not support the radical movement to establish an Islamic State in Indonesia. Islamic Religious Education (PAI), as taught and developed using Indonesian teachers' character-building efforts, presents Islam from various perspectives, including cultural, social, and psychological, and with diverse scientific aspects.

This corresponds to the words of Mr. Mufiq, Vice Dean of Academics at IAIN Salatiga, saying that "the values of character-building in IAIN Salatiga are excavated from various scientific frameworks including from Qur'an and Hadith without neglecting historical aspects and communal social conditions in Indonesia. It is expected to deliver the message that the outside world should not understand Islam in Indonesia as being in black \& white as most people taught". All of the stages getting to the end, it will more be instilled within students, so that, it will take a long time and effort to achieve the desired outcome. It is illustrated in the following chart:

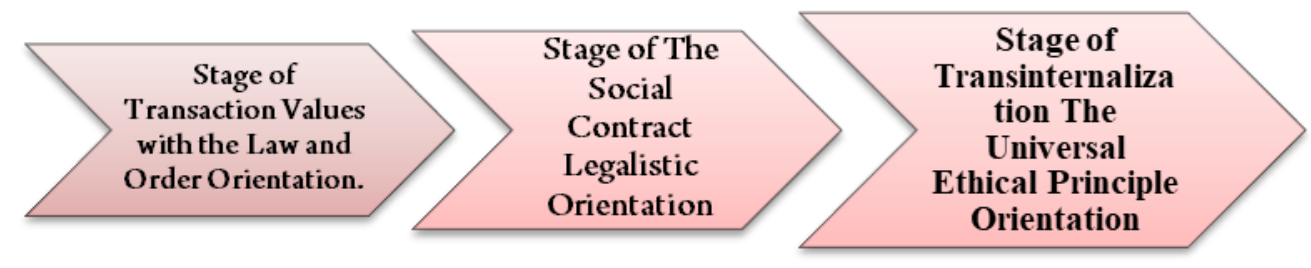

Chart 1. Stages of Values Internalization 


\section{Conclussion}

With this research, it can be concluded that Islamic colleges must be integrated with local culture to further develop and make progress amid modernization and digitalization. Science integration applied by IAIN Salatiga is a triadic integration model and the three-door model of integration that uses integration of science and Islamic values connected with Indonesian/Javanese local cultural values. This internalization process is integrated with Islamic and Indonesian values taught to students so that they build strong character as Muslim scholars who are integrated with the local cultures. They also are responsible to promote the aforementioned missions of FTIK IAIN Salatiga. Meanwhile, the internalization of Indonesian Islamic values in FTIK IAIN Salatiga is conducted in three stages:

The first stage of values transaction is carried out in all lecturing and extracurricular activities by considering law, social regulation, and student obligation, in order to prepare the student to serving society, state, and religion. Second, in the social contract stage, students have understood that everything they do in society will influence the community's social status. This encourages students to actively follow the community's social flow, such as by participating in mutual-assistance projects for cleaning the environment, and in cultural and religious activities, such as presented in Sea Alms, Tahlilan, etc. Third, the stage of transinternalization denotes the success of the internalization process obtained during college study in FTIK IAIN Salatiga. In this third stage, students have studied and internalized universal values developed within the society. 


\section{REFERENCES}

Abdullah, MA. 2017. "Islamic Studies in Higher Education in Indonesia: Challenges, Impact and Prospects for the World Community." Al-Jami'ah: Journal of Islamic Studies, 55 (2): 391-426. https://aljamiah.or.id/index.php/AJIS/article/view/837

Alam, L. 2016. “Internalisasi Nilai-Nilai Pendidikan Islam Dalam Perguruan Tinggi Umum Melalui Lembaga Dakwah Kampus.” Istawa: Jurnal Pendidikan Islam, 1(2): 101-122. http://journal.umpo.ac.id/index.php/istawa/article/view/171/0

Bagir, ZA. 2005a. Integrasi Ilmu Dan Agama: Interpretasi dan Aksi. Bandung: Mizan.

Bagir, ZA. 2005b. Islam, Science, and 'Islamic Science': How to 'integrate'science and Religion: Science and Religion in a Post-Colonial World. Interfaith Perspectives. Australia: Atf Press.

Bahar, S. 1991. Perjuangan Menuju Persatuan Dan Kesatuan Bangsa. Semarang: Mandira Jaya Abadi

Bazargan, A. 2018. An Introduction to Qualitative and Mixed Methods Research (Approaches in the Behavioral Sciences). Tehran: Didar Publications.

Berkowitz, M. W., Lickona, T., Nast, T., Schaeffer, E., \& Bohlin, K. (2020). "The Eleven Principles Of Effective Character Education: A Brief History". Journal of Character Education, 16 (2), 1-10.

Cahyono, H. 2016. "Pendidikan Karakter: Strategi Pendidikan Nilai Dalam Membentuk Karakter Religius.” Ri'ayah: Jurnal Sosial Dan Keagamaan, 1 (2); 230-240.

Huberman, M., and MB Miles. 2002. The Qualitative Researcher's Companion. books.google.com.

Ihsan, F. 2011. "Dasar-DasarKependidikan. Jakarta: RinekaCipta.

Lickona, T. 2012. "Action in Teacher Education Character Education: Seven Crucial Issues". (2), 37-41. https://ur.booksc.org/book/311922615/e36e27

Lickona, T., E. Schaps, and C. Lewis. 2007. “CEP's Eleven Principles of Effective Character Education." Character Education Partnership, $20 \quad$ (4): 77-84. https://eric.ed.gov/?id=ED505086

Miles, MB, and AM Huberman. 1994. Qualitative Data Analysis: An Expanded Sourcebook. Miles, MB, AM Huberman, and J. Saldaña. 2018. Qualitative Data Analysis: A Methods Sourcebook. 
Muhaimin, A. 2014. "Character Building through Islamic Schools: An Analytical Study." Tahdhīb al Afkār, 1 (1); 15-29. http://iri.aiou.edu.pk/indexing/wpcontent/uploads/2016/06/02-character-building-through-islamic-schools.pdf

Mulyana, R. 2004. Mengartikulasikan Pendidikan Nilai. Bandung: Alfabeta.

Mulyana, R. 2018. Model Pembelajaran Nilai Melalui Pendidikan Agama Islam (PAI). Jakarta, Saadah Pustaka Mandiir.

Nugroho, P. 2017. "Internalisasi Nilai-Nilai Karakter Dan Kepribadian Mahasiswa Pendidikan Agama Islam Melalui Pendekatan Humanis-Religius.” Edukasia: Jurnal Penelitian $\begin{array}{lll}\text { Pendidikan } \quad 12 & \text { Islam, } & \text { 355-382. }\end{array}$ http://journal.iainkudus.ac.id/index.php/Edukasia/article/view/2491

Pashiardis, P., S. Brauckmann, P. Sammons, and ... 2011. "Exploring the Impact of School Leadership on Pupil Outcomes." International Journal of educational management, 25

101.https://www.emerald.com/insight/content/doi/10.1108/09513541111100134/full /html.

Poerwadarminta, WJS. 2014. "Kamus Bahasa Indonesia Lengkap. Jakarta: PT.” Balai Pustaka. Rumiani. 2006. Prokrastinasi Akademik Ditinjau Dari Motivasi Berprestasi Dan Stress Mahasiswa." Jurnal Psikologi Universitas Diponegoro, 3 (2): 37-48. https://ejournal.undip.ac.id/index.php/psikologi/article/view/656/530

Sugiyono, S. 2010. Educational Research Methods: Quantitative, Qualitative, and R \& D Approaches. Bandung: CV. Alfabeta.

Suryani, K., BD Hardika, and MT Rini. 2020. "Studi Fenomenologi: Pengalaman Remaja

Dalam Menggunakan Narkoba.” Jurnal Keperawatan Silampari, 4(1), 120-134. doi; 10. 31539/jks.v4i1.1601.

Susanti, T., A. Suryadin, and MS Sumantri. 2020. "Pengukuran Kenakalan Remaja pada Siswa Menengah di Kabupaten Bangka Barat.” Media Bina Ilmiah, 15(4), 4291-4301.

Sutjipto, S. 2011. "Rintisan Pengembangan Pendidikan Karakter Di Satuan Pendidikan." Jurnal Pendidikan Dan Kebudayaan, 17 (5), 501-524. https://www.neliti.com/publications/123419/rintisan-pengembangan-pendidikankarakter-di-satuan-pendidikan

Syafi'AS, A., and Y. Rahmawati. 2019. "Upaya Guru Agama Islam Dalam Mengatasi Problematika Kenakalan Remaja (Studi Kasus Di SMA Avicenna Mojongapit Jombang).” Sumbula, Sumbula, 4 (1), 1-24. 
Tricahyono, D., S. Sariyatun, and Edi. 2020. "Analisis Wacana Kritis Pendidikan Multikultural Dan Pendidikan Nilai Dalam Buku Teks Sejarah SMA.” SOCIA: Jurnal Ilmu-Ilmu Sosial, 17 (1); 1-10. https://journal.uny.ac.id/index.php/sosia/article/view/32294

Wahyuni, DD, and MD Nurmala. 2020. "Profil Kenakalan Remaja Dan Implikasinya Terhadap Program Bimbingan Pribadi-Sosial.” Foundasia, 11(2), 69-73.

Wathoni, K. 2016. "Internalisasi Pendidikan Karakter di Perguruan Tinggi: Studi Kasus Di Jurusan Tarbiyah STAIN PONOROGO.” Didaktika Religia, 2(1): 1-20. https://jurnal.iainkediri.ac.id/index.php/didaktika/article/view/130

Zubaedi, DPK. 2011. Konsepsi Dan Aplikasinya Dalam Lembaga Pendidikan. Jakarta: Kencana. 
